\title{
Students Evaluation of Faculty
}

\author{
Ahmad M. Thawabieh ${ }^{1}$ \\ ${ }^{1}$ Department of Educational Psychology, Faculty of Educational Sciences, Tafila Technical University, Jordan \\ Correspondence: Ahmad M. Thawabieh, Department of Educational Psychology, Faculty of Educational \\ Sciences, Tafila Technical University, Jordan. Tel: 96-277-775-8156. E-mail: ahmadthawabieh@yahoo.com
}

Received: August 16, 2016

doi:10.5539/ies.v10n2p35
Accepted: September 23, $2016 \quad$ Online Published: January 30, 2017

URL: http://dx.doi.org/10.5539/ies.v10n2p35

\begin{abstract}
This study aimed to investigate how students evaluate their faculty and the effect of gender, expected grade, and college on students' evaluation. The study sample consisted of 5291 students from Tafila Technical University Faculty evaluation scale was used to collect data. The results indicated that student evaluation of faculty was high $($ mean $=4.14$, S.D. $=0.79)$ and there were statistically significant differences in students' evaluation attributed to students' gender, college and expected grade in the course.
\end{abstract}

Keywords: faculty, evaluation, teaching, university

\section{Introduction}

Many academic institutions encourage faculty to improve their quality of teaching; so they established centers for faculty development in order to provide student with the best teaching practices, fair assessment and suitable behavior with them. Tafila Technical University established Faculty Development Center since 2010; at the end of each semester routinely the student evaluates the effectiveness and quality of their faculty in teaching, because students' evaluation is mainly the most common method used by the university administration to evaluate faculty. The purpose of faculty evaluation by students may help faculty to identify areas of strength and weakness in order to help them to improve their teaching practices, and provide them with their students' views about them. Faculty evaluation is considered to be one of the most important objectives for any academic institution in order to ensure that these institutions achieved their goals in graduating highly qualified students, provide faculty with feedback about their performance, promote faculty to higher ranks, and provide feedback to the decision makers about faculty. Mellhem (2011) focused on the following instructional tasks that faculty has to do in the classroom: determination of learning outcomes, determination pre-requests for achieving the learning outcomes, planning the suitable instructional strategies to the learning outcomes, providing student with motivation to learn, and choosing the assessment strategies.

The student is considered to be the person who is able to evaluate his/ her teacher; he/ she can determine the characteristics of the good teacher; because he/ she can estimate the effect of the teacher upon his progress. Melhm (2011) summarized the study results of the ideal teacher characteristics from students' perspectives: humanity traits; such as emotional and sympathy for students, ethics which includes: attitudes and values, appearance: clothes and voice, expert in his subject, and leadership. Coburn (1984) indicated that students are the main source of information about the learning environment.

Allam (2007) identified 4 competencies that faculty member must had concerning students' assessment: a) appropriate assessment methods and tools, b) suitable application and scoring techniques, c) using the assessment results to improve teaching and assessment strategies, d) provide feedback about assessment to students, parents and decision makers. Barrett (1986) indicated that student-teacher evaluation could be used to develop learning environment. Rubin (1981) identified 5 traits students rated high for ideal faculty: a) expertise, b) professionalism, c) ability to communicate, d) openness to students and their ideas; and e) being nurturing and supportive.

Wright (2000) found that the fairness in Assessment and faculty appearance were strongly related to students' evaluation of faculty, although these factors may be unrelated to learning process.

Gursoy and Umbreit (2005) find that students' evaluation could be biased by the personality and popularity of the faculty. Baldwin and Blattner (2003) indicated that students' gender, the time of day the class is held, the difficulty of the class being taught and the class size affect teachers evaluation by students. 
The study of Mcpherson (2006) determined the factors that influence the students' evaluation of the instructors; he found that awarding higher grades to students, large class size and the level of experience of the instructor were the determinants of how students evaluate instructors.

Kaylani (2006) indicated that $60 \%$ of faculty members in eight Jordanian universities showed unfavorable attitudes toward students' evaluation of faculty members. Large proportion $(60 \%)$ of faculty members agreed that every instructor should be acquainted with student ratings of his performance. About the same proportion indicates that the way this activity is done should be reconsidered. The study concluded that students' evaluation would not give valid indices of the effectiveness of faculty development programs.

The study of Remedios and Lieberman (2008) used 765 students studying psychology at a Scottish university to determine the influence of grades, workload, expectations and goals on students' evaluations of teaching. The results indicated that grades, course difficulty, and expectations did have small positive influence on faculty rating, but the determinant factor was how much students enjoy or felt stimulated by the course content, which in turn depended upon the quality of teaching.

The study of Kneipp, Kelly, Buiscoe, and Richard (2010) indicated that agreeableness was correlated with instructional quality from student ratings of teachers.

Shaub-de Jong, Schonrock-Adema, Dekker, Verkerk, and Cohen-Schotanus (2011) developed a student rating scale to evaluate teachers competencies for facilitating reflective learning, the scale yielded three components: supporting self-insight, creating a safe environment, and encouraging self-regulation.

\subsection{Study Statement}

This study aimed to evaluate Faculty by their students, precisely the study will answer the following questions:

1) How do the students evaluate faculty?

2) Are their statistical differences in students' evaluation attributed to college?

3) Are their statistical differences in students' evaluation attributed to students' gender?

4) Are their statistical differences in students' evaluation attributed to the final grade that the student expected to have in the course?

\subsection{Importance of the Problem}

This study highlights the effectiveness of student' evaluation of their faculty, provide decision makers with clear information about the learning environment from students' perspectives and the influence of some factors that may affects students' evaluation of the faculty.

\section{Methodology}

\subsection{Design}

The study adopted the descriptive approach due to its relevance to answer the study questions.

\subsection{Study Sample}

The sample of the study consisted of one course/ faculty, the number of students involved in evaluation $=5291$.

Table 1 represents the students' distribution according to college and gender. 
Table 1. Study Sample

\begin{tabular}{llcc}
\hline Faculty & & Frequency & Percent \\
\hline \multirow{4}{*}{ Engineering } & male & 1002 & 70.0 \\
& female & 430 & 30.0 \\
& total & 1432 & 100 \\
& male & 524 & 49.4 \\
Science & female & 536 & 50.6 \\
& total & 1060 & 100 \\
Education & male & 461 & 45.1 \\
& female & 562 & 54.9 \\
& total & 1023 & 100 \\
Business & male & 394 & 40.2 \\
& female & 586 & 59.8 \\
& total & 980 & 100 \\
Arts & male & 302 & 37.9 \\
& female & 494 & 62.1 \\
& total & 796 & 100 \\
\hline
\end{tabular}

\subsection{Instrument}

The instrument used to collect data was the faculty evaluation scale, which is used by Faculty Development Center at Tafila Technical University.

\subsection{Validity}

The validity for the instrument was checked during the process of developing it to be used as faculty evaluation scale, at that time it was sent to 10 experts in assessment, curricula, and educational psychology from Jordanian universities, according to their $90 \%$ agreement, it was modified and had its final form.

The instrument consisted of 30 items, 4 domains: syllabus ( 6 items), instruction methods ( 8 items), assessment (9 items), and faculty personal characters ( 7 items).

\subsection{Reliability}

Reliability was approved by using internal consistency (Cronbach $\alpha$ equation). A pilot sample consisted of 70 students was used, they were chosen randomly. Table 2 represents the findings of the reliability.

Table 2. Reliability

\begin{tabular}{lc}
\hline Domain & Cronbach $\alpha$ \\
\hline Syllabus & 0.91 \\
Instruction methods & 0.89 \\
Assessment & 0.90 \\
Personal characteristics & 0.89 \\
Total & 0.96 \\
\hline
\end{tabular}

\subsection{Procedure}

The evaluation scale was administered to the study sample before the end of the selected course used to evaluate the faculty, researcher and co-researchers performed this task, the faculty were asked to leave the class before the students started to respond to the scale, students were asked to express their opinion freely and honestly, they informed that their responses were valuable and will be confidential. The students were asked to respond to each item using likert scale $(1=$ strongly disagree, $2=$ disagree, $3=$ neutral, $4=$ agree, $5=$ strongly agree $)$. The researcher used the following criteria to describe the means of domains and items of the scale: 1-2.33 low, 2.34-3.64 moderate, and 3.65-5 high.

\subsection{Variables}

Independent variables: Gender (male, female), College (Scientific: Engineering, and Science, Humanity: Education, Business and Arts), Expected grade in the course (less than 59, 60-79, more than 79).

Dependent variable: Evaluation degree of the faculty by students. 
Statistics: Means, Standard Deviations, MANOVA and post comparison tests were used to answer the study questions.

\section{Results}

\subsection{Question 1}

To answer the $1^{\text {st }}$ question (How does the student evaluated faculty?) Means and standard deviations were used. Table 3 represents the findings of this question.

Table 3. Means and standard deviations of students' evaluation of the faculty

\begin{tabular}{|c|c|c|c|c|}
\hline Domain & & Means & Standard & Degree \\
\hline \multirow{6}{*}{ Syllabus } & $\begin{array}{l}\text { The instructor distribute the study plan in the beginning of the } \\
\text { academic semester }\end{array}$ & 4.31 & 1.203 & high \\
\hline & $\mathrm{He}$ is committed practically in implementing the plan & 4.09 & 1.166 & high \\
\hline & The instructor limits the dates of tests in the plan & 4.04 & 1.302 & high \\
\hline & The instructor presents a comprehensive and detailed plan & 4.00 & 1.232 & high \\
\hline & The instructor discusses the plan with students & 3.97 & 1.270 & high \\
\hline & The plan includes a list of current references & 3.91 & 1.272 & high \\
\hline \multirow[t]{4}{*}{ Total } & & 4.05 & 1.03 & high \\
\hline & $\mathrm{He}$ is committed in lectures time & 4.48 & .945 & high \\
\hline & He exploits the time of lecture in teaching & 4.36 & .968 & high \\
\hline & He is versed of his subject & 4.28 & 1.074 & high \\
\hline \multirow{5}{*}{$\begin{array}{l}\text { Instruction } \\
\text { methods }\end{array}$} & He uses accurate language during displaying the material & 4.21 & 1.077 & high \\
\hline & He displays the material in an organized way & 4.13 & 1.121 & high \\
\hline & He accepts the students' ideas and he activates their roles & 4.08 & 1.133 & high \\
\hline & He takes into account the individual differences of students & 3.91 & 1.200 & high \\
\hline & He uses various teaching aids and methods of teaching & 3.76 & 1.255 & high \\
\hline \multirow[t]{4}{*}{ Total } & & 4.15 & 0.85 & high \\
\hline & He is serious and strict when applying tests & 4.42 & .916 & high \\
\hline & $\begin{array}{l}\text { He corrects the tests and give them back to students in the } \\
\text { appropriate time }\end{array}$ & 4.29 & 1.029 & high \\
\hline & He holds tests at the appointed time in the plan & 4.18 & 1.139 & high \\
\hline \multirow{6}{*}{ Assessment } & He accepts students revision for their papers & 4.17 & 1.118 & high \\
\hline & The questions cover the content the subject & 4.15 & 1.109 & high \\
\hline & He uses various questions in his tests & 4.12 & 1.128 & high \\
\hline & He assessed the student performance fairly and subjectively & 4.07 & 1.116 & high \\
\hline & He discusses the questions and the answers with students & 4.05 & 1.169 & high \\
\hline & The questions are clear & 3.96 & 1.210 & high \\
\hline \multirow[t]{4}{*}{ Total } & & 4.15 & 0.83 & high \\
\hline & He is careful in following up students absence and attendance & 4.41 & .991 & high \\
\hline & He deals respectively with students & 4.35 & 1.037 & high \\
\hline & He makes his behavior as a model for his students & 4.22 & 1.116 & high \\
\hline \multirow{4}{*}{$\begin{array}{l}\text { Personal } \\
\text { characteristics }\end{array}$} & He is committed with office hours & 4.13 & 1.091 & high \\
\hline & He presents advice, consult for students & 4.10 & 1.145 & high \\
\hline & $\begin{array}{l}\mathrm{He} \text { provides the lecture with interesting and friendly } \\
\text { atmosphere }\end{array}$ & 4.01 & 1.237 & high \\
\hline & He interest in students' creative ideas & 3.99 & 1.164 & high \\
\hline Total & & 4.17 & 0.85 & high \\
\hline Grand Total & & 4.14 & 0.79 & \\
\hline
\end{tabular}

According to table 3 the students evaluation of the faculty was high (mean $=4.14$, S.D $=0.79$ ), all domains of the scale were also high, the highest one was personal characteristics (mean $=4.17$, S.D $=0.85$ ), then assessment and instruction methods with equal mean $($ mean $=4.15)$, while the lowest domain was the syllabus (mean $=4.05$, $\mathrm{S} . \mathrm{D}=1.03)$. 


\subsection{Question 2}

To answer the $2^{\text {nd }}$ question (Are their statistical differences in students' evaluation attributed to college?) means, standard deviations and MANOVA were used. Table 4 represents the means and standard deviation for faculty according to college.

Table 4. Means and standard deviations for faculty evaluation according to college

\begin{tabular}{llcccc}
\hline Faculty & & Syllabus & Instruction methods & Assessment & Personal characteristics \\
\hline Engineering & Mean & 3.7534 & 3.9489 & 3.9703 & 4.0093 \\
& Std. deviation & 1.13371 & .90175 & .84436 & .87299 \\
Science & Mean & 4.0407 & 4.1501 & 4.2042 & 4.1655 \\
& Std. deviation & 1.03023 & .85619 & .80585 & .84288 \\
Education & Mean & 4.2877 & 4.3331 & 4.3267 & 4.2952 \\
& Std. deviation & .88495 & .77 .39 & .77094 & .83910 \\
\multirow{2}{*}{ Business } & Mean & 4.1526 & 4.1533 & 4.1396 & 4.1773 \\
& Std. deviation & .98522 & .83870 & .84968 & .86938 \\
& Mean & 4.1912 & 4.2736 & 4.2239 & 4.3042 \\
& Std. deviation & .98255 & .78287 & .82539 & .81018 \\
\hline
\end{tabular}

According to Table 4 Education College had the highest mean in all domains, while Engineering College had the lowest in all domains, in order to indicate if these differences in means were significant, Wilks' Lambda was used, Table 5 represent the findings.

Table 5. Wilks' Lambda for the effect of college upon students' evaluation of the faculty

\begin{tabular}{lcccccc}
\hline Variable & Test & Test value & F & d.f & Significant & Partial Eta Squared \\
\hline College & Wilks' Lambda & 0.95 & 17.003 & 16 & 0.000 & 0.013 \\
\hline
\end{tabular}

According to Table 5 there were significant differences in students' evaluation of the faculty attributed to college. In order to determine the dependent variables resulted in college effect MANOVA was used. Table 6 represents the findings.

Table 6. MANOVA for the effect of college upon students' evaluation

\begin{tabular}{llcccccc}
\hline Source & Dependent variable & Sum of squares & df & Mean Squares & F & Sig & Partial Eta Squared \\
\hline \multirow{5}{*}{ College } & syllabus & 209.978 & 4 & 52.494 & 50.623 & 0.000 & 0.037 \\
& instruction & 104.346 & 4 & 26.087 & 37.044 & 0.000 & 0.027 \\
& assessment & 85.598 & 4 & 21.399 & 31.741 & 0.000 & 0.023 \\
& Personal characteristics & 67.428 & 4 & 16.857 & 23.300 & 0.000 & 0.017 \\
error & syllabus & 5481.396 & 5286 & 1.037 & & & \\
& instruction & 3722.401 & 5286 & 0.704 & & & \\
& assessment & 3563.760 & 5286 & 0.674 & & & \\
\multirow{5}{*}{ Total } & Personal characteristics & 3824.299 & 5286 & 0.723 & & & \\
& syllabus & 92650.833 & 5291 & & & & \\
& instruction & 94960.125 & 5291 & & & & \\
& assessment & 95018.296 & 5291 & & & & \\
& Personal characteristics & 95955.633 & 5291 & & & & \\
\hline
\end{tabular}

In order to determine to which faculty these differences are in favor of. Table 7 represents the findings 
Table 7. Tuky test for post comparisons between scale domains and college

\begin{tabular}{|c|c|c|c|c|c|c|}
\hline Domain & & Art & Business & Education & Science & Engineering \\
\hline \multirow{5}{*}{ Syllabus } & Engineering (3.75) & $0.4378 *$ & $0.3992 *$ & $0.5343^{*}$ & $0.2873^{*}$ & \\
\hline & Science(4.04) & $0.1504 *$ & 0.1118 & $0.2470^{*}$ & & \\
\hline & Education (4.28) & 0.0966 & $0.1352 *$ & & & \\
\hline & Business (4.15) & .0386 & & & & \\
\hline & Arts (4.19) & & & & & \\
\hline \multirow{5}{*}{ Instruction } & Engineering (3.9489) & $.3246^{*}$ & $0.2044^{*}$ & $.3842 *$ & $.2012^{*}$ & \\
\hline & Science( 4.1501$)$ & $.1234 *$ & .0032 & $.1830^{*}$ & & \\
\hline & Education (4.33) & .0595 & $.1798^{*}$ & & & \\
\hline & Business (4.15) & $.1202 *$ & & & & \\
\hline & Arts (4.27) & & & & & \\
\hline \multirow{5}{*}{ Assessment } & Engineering (3.97) & $.2536^{*}$ & $.1693^{*}$ & $.3564 *$ & $.2339^{*}$ & \\
\hline & Science( 4.20$)$ & .0197 & .0646 & $.1225^{*}$ & & \\
\hline & Education (4.32) & .1028 & $.1871^{*}$ & - & & \\
\hline & Business (4.13) & .0843 & - & - & & \\
\hline & Arts (4.22) & - & - & - & & \\
\hline \multirow{5}{*}{ Personal characteristics } & Engineering (4.00) & $.2949 *$ & $.1680^{*}$ & $.2859^{*}$ & $.1562 *$ & \\
\hline & Science $(4.17)$ & $.1387^{*}$ & .0118 & $.1297 *$ & & \\
\hline & Education (4.30) & .0090 & $.1180^{*}$ & & & \\
\hline & Business (4.19) & $.1269 *$ & & & & \\
\hline & Arts (4.30) & & & & & \\
\hline
\end{tabular}

$* \alpha=0.05$.

As shown in Table 7 the differences were significant in the favor of Education College in all domains and for Art College in syllabus, instruction and personal characteristics.

\subsection{Question 3}

The $3^{\text {rd }}$ question: Are their statistical differences in students' evaluation attributed to students' gender?

To answer this question means and standard deviation were used. Table 8 represents the findings of the students' evaluation according to their gender.

Table 8. Means and standard deviations for faculty evaluation according to students' gender

\begin{tabular}{lccc}
\hline & Gender & Mean & Std. Deviation \\
\hline \multirow{3}{*}{ Syllabus } & Male & 4.0006 & 1.07642 \\
& Female & 4.1090 & .99255 \\
Instruction & Total & 4.0541 & 1.03724 \\
& Male & 4.1224 & .90942 \\
Assessment & Female & 4.1788 & .78449 \\
& Total & 4.1502 & .85052 \\
& Male & 4.1146 & .88916 \\
Personal characteristics & Female & 4.1977 & .76353 \\
& Total & 4.1556 & .83058 \\
& Male & 4.1491 & .89012 \\
& Female & 4.1942 & .82259 \\
\hline
\end{tabular}

According to Table 8 female students' evaluation was higher than male students, MANOVA was used and it is found that the differences were significant in favor of females for syllabus, instruction and assessment domains, while the difference was not significant for personal characteristics. Tables 9 and 10 represent the above findings. 
Table 9. Hotelling's Trace Test for the effect of students' gender upon faculty evaluation

\begin{tabular}{lcccccc}
\hline Variable & Test & Value & F & df & Sig & Partial Eta Squared \\
\hline Gender & Hotelling's Trace & 0.004 & 5.454 & 4 & 0.000 & 0.004 \\
\hline
\end{tabular}

Table 10. MANOVA for the effect of gender upon evaluation domains

\begin{tabular}{lccccccc}
\hline Source & Dependent variable & Sum of squares & df & Mean Squares & F & Sig & Partial Eta Squared \\
\hline \multirow{4}{*}{ Gender } & Syllabus & 15.541 & 1 & 15.541 & 14.481 & 0.000 & 0.003 \\
& Instruction & 4.198 & 1 & 4.198 & 5.808 & 0.016 & 0.001 \\
& assessment & 9.140 & 1 & 9.140 & 13.280 & 0.000 & 0.003 \\
\multirow{5}{*}{ Error } & Personal Characteristics & 2.683 & 1 & 2.683 & 3.649 & 0.056 & 0.001 \\
& Syllabus & 5675.833 & 5289 & 1.073 & & & \\
& Instruction & 3822.550 & 5289 & 0.723 & & & \\
\multirow{6}{*}{ Total } & assessment & 3640.217 & 5289 & 0.735 & & & \\
& Personal Characteristics & 3889.044 & 5289 & 1.073 & & & \\
& Syllabus & 92650.833 & 5291 & & & & \\
& Instruction & 94960.125 & 5291 & & & & \\
& assessment & 95018.296 & 5291 & & & & \\
& Personal Characteristics & 95955.633 & 5291 & & & & \\
\hline
\end{tabular}

\subsection{Question 4}

The $4^{\text {th }}$ question: Are their statistical differences in students' evaluation attributed to the final grade that the student expected to have in the course? To answer this question means and standard deviations were calculated, Table 11 represents the findings.

Table 11. Means and standard deviations for faculty according to the expected final grade

\begin{tabular}{lccc}
\hline & Final Grade & Mean & Std. Deviation \\
\hline Syllabus & less59 & 3.6302 & 1.15128 \\
& $60-79$ & 4.0887 & 1.01082 \\
& $>79$ & 4.2042 & .96436 \\
Instruction & Total & 4.0541 & 1.03724 \\
& less59 & 3.6842 & 1.02636 \\
& $60-79$ & 4.1581 & .81058 \\
Assessment & $>79$ & 4.3619 & .72025 \\
& Total & 4.1502 & .85052 \\
& less59 & 3.6930 & 1.00131 \\
Personal characteristics & $60-79$ & 4.1633 & .79695 \\
& $>79$ & 4.3658 & .69118 \\
& Total & 4.1556 & .83058 \\
& less59 & 3.7340 & 1.04034 \\
& $60-79$ & 4.1741 & .82564 \\
& $>79$ & 4.3772 & .72046 \\
& Total & 4.1713 & .85772 \\
\hline
\end{tabular}

The results from Table 11 indicates that students who expected higher grades $(>79)$ were highly evaluated faculty, while students with lower grades (less than 59) gave low evaluation to their faculty, Wilks' Lambda and MANOVA were used to examine if these differences were statistically significant, table 12 and 13 represents these findings using Wilks' Lambda. 
Table 12. Wilks' Lambda for the effect of grade upon students' evaluation

\begin{tabular}{ccccccc}
\hline Variable & Test & Value & F & df & Sig & Partial Eta Squared \\
\hline Expected final mark & Wilks' Lambda & 0.922 & 54.872 & 8 & 0.000 & 0.04 \\
\hline
\end{tabular}

As indicted in table 12 the differences were significant. Table 13 represents MANOVA analysis for the effect of expected final mark upon domains of evaluation.

Table 13. MANOVA for the effect of students' final grade upon evaluation domains

\begin{tabular}{lccccccc}
\hline Source & Dependent variable & Sum of squares & df & Mean Squares & F & Sig & Partial Eta Squared \\
\hline Expected Final Mark & Syllabus & 193.791 & 2 & 96.895 & 93.201 & 0.000 & 0.034 \\
& Instruction & 261.331 & 2 & 130.666 & 193.795 & 0.000 & 0.068 \\
& Assessment & 257.549 & 2 & 128.775 & 200.766 & 0.000 & 0.071 \\
& Personal Characteristics & 235.067 & 2 & 117.533 & 169.969 & 0.000 & 0.060 \\
Error & Syllabus & 5497.583 & 5288 & 1.040 & & & \\
& Instruction & 3565.416 & 5288 & 0.674 & & & \\
& Assessment & 3391.809 & 5288 & 0.641 & & & \\
Total & Personal Characteristics & 3656.660 & 5288 & 0.692 & & & \\
& Syllabus & 92650.833 & 5291 & & & & \\
& Instruction & 94960.125 & 5291 & & & & \\
& Assessment & 95018.296 & 5291 & & & &
\end{tabular}

Table 13 indicated that the final mark had significant effect upon students, evaluation on all evaluation domains. Tuky test for post comparisons was used and it is found that these differences were significant in the favor of high expected grades (> 79).

\section{Discussion}

The results indicated high evaluation of the faculty from their students. This may due to the fact that Tafila Technical University was a new university and had an enthusiastic faculty and most of them were graduated from well known, high ranked universities, and it may also due to the competitive process in selecting them to be employed at the university.

Humanity college faculty (Education, Arts, and Business) had higher evaluation compared to the faculty from scientific colleges (Science and Engineering) this may be resulted from the nature of courses the faculty studied during their academic life and the nature of courses they used to teach to their students; these courses had a humanity nature, education college used to train others how to deal with students, how to taught them using different instructional methods and assessment strategies. This also could be due to the fact that most of the students in scientific colleges were males, and according to this study results males evaluated faculty lower than females.

The results indicated that students who expected higher marks in the course evaluated faculty higher than those who expected lower marks, This could be explained according to the psychological issues: highly achieved students are more motivated to study and they know exactly what is going on the learning environment, while the low achievers had to find excuses for their low achievement by attributing their failure upon outside factors; one of these factors was faculty, so they gave them low evaluation, this result was similar to the finding of Allam (2007), McPherson (2006), Remedios and Liberman (2008), and wright (2000).

Female students evaluated faculties higher than males, this could be explained by the fact that females were more motivated and had higher achievement than males, so they were more familiar with learning environment than males, so they may be accurate in evaluation than males, or it could be due to the physiological nature of females, they were more sympathy and kind compared with the males, this result was similar with the finding of Baldwin and Blattner (2003).

\section{Conclusion}

The study was designed to find how students evaluate their faculty and the effect of gender, expected grades, and college on their evaluations. in Summary, the results indicated that grades, gender, and college affect students' evaluation of faculty. 


\section{Recommendations}

With respect to future research, it would be helpful to take into consideration other factors which may affect students' evaluation of faculty such: course difficulty, experience of instructors, class size, students' academic level, time the course had been taught, and faculty gender. Other studies should be conducted to compare between students' evaluation of the faculty in the same college. The researcher also recommends investigating the ideal instructor from students' perspectives.

\section{References}

Allam, S. (2007). Measurement and Educational assessment. Amman: Dar Almasira.

Baldwin, T., \& Blattner, N. (2003). Guarding against potential bias in student evaluations. College Teaching, 51(1), 27-32. https://doi.org/10.1080/87567550309596407

Barrett, J. (1986). Evaluation of students teachers. Retrieved from https://www.eric.edu.gov

Coburn, L. (1984). Student evaluation of teachers'performance. Retrieved from https://www.eric.edu.gov

Gursoy, D., \& Umbreit, W. (2005). Exploring students' evaluation of teaching effectiveness: what factors are important? Journal of Hospitality Tourism Research, 29(1), 91-109.

Kaylani, A. (2006). Evaluation of faculty development center (FDCS) at eight public universities in the Hashemite Kingdom of Jordan. Amman: National center for human resources development.

Kneipp, L., Kelly, B., Biscoe, K., \& Richard, J. (2010). The impact of instructors' personality characteristics on quality of instruction. College Student Journal, 44(4), 901-905.

McPherson, M. (2006). Determinants of how students evaluate teachers. Research in Economic Education, 37(1), 3-20. https://doi.org/10.3200/JECE.37.1.3-20

Melhm, S. (2011). Measurement and Evaluation in Education and Psychology. Amman. Dar Almasira.

Remedies, R., \& Lieberman, D. (2008). I liked your course you taught me well: the influence of grades, workload, expectations and goals on students' evaluation of teaching. British Educational Research Journal, 34(1), 91-115. https://doi.org/10.1080/01411920701492043

Rubin, R. (1981). Ideal traits and terms of address for male and female college professors. Journal of Personality \& Social Psychology, 41(5), 966-974. https://doi.org/10.1037/0022-3514.41.5.966

Schaub-de jong, M., Schonrock-Adems, J., Dekker, H., Verkerk, M., \& Cohen-Schotanus, J. (2011). Development of a student rating scale to evaluate teachers' competencies for facilitating reflective learning. Medical Education, 45, 155-165. https://doi.org/10.1111/j.1365-2923.2010.03774.x

Wright, R. (2000). Students' evaluations and consumer orientation of universities. Journal of Nonprofit and Public Sector Marketing, 8, 33-40. https://doi.org/10.1300/J054v08n01_04

\section{Copyrights}

Copyright for this article is retained by the author(s), with first publication rights granted to the journal.

This is an open-access article distributed under the terms and conditions of the Creative Commons Attribution license (http://creativecommons.org/licenses/by/4.0/). 